\title{
A Hundred TeXts on Nordic Museums in 'Museum'
}

\section{John Aage Gjestrum}

In 1948 UNESCO and ICOM started to publish "Museum». During 47 years this journal has been an important source of information to the world of museums and museology. The bibliography presented here gives access to 100 articles by Nordic authors in the period $1948-1994$.

In July 1948 the first issue of Museum was presented by UNESCO, introduced as a successor of Museion (published before World War II by the League of Nations). A board of editors counted 29 distinguished museum professionals, also including two from the Nordic countries; Thorsten Althin and Bengt Thordeman, both of them from Stockholm, Sweden.

The first issue was a double issue (12/1948) and devoted to French Museums, since the first international museum conference after World War II - the first General Conference of ICOM - should take place in Paris in that year.

The first Nordic article was published by Gösta Selling in the second issue: «Educational Work in Swedish Museums» (3-4/1948). However the whole next issue (1949/1) is devoted to Sweden, - which according to the editor, has «one of the most interesting museum systems in the world»:

Museum people from the Americas and from other European countries, visiting Sweden have found remarkable a number of aspects of museums development there. The recent rapid growth of the museums, their modern museographical techniques and general high standards, their influence on the population at large ( 70 per cent of the population is reported to visit museums in Sweden annually!) and the role they fulfil in the ordinary educational system of the country, have attracted attention (Museum 1949/1: 4).

Bengt Thordeman, head of the Medieval Department of the recently opened Museum of National Antiquities in Stockholm, wrote the introduction, giving both the history of Swedish museums and a nation-wide presentation, including the 700 open-air museums. Accompanied by 126 (!) illustrations this issue of Museum really made Sweden known among museum professionals all over the world.

It is easy to discover at least one important reason to the strong position of Swedish museums in the 1940's. During those years most European countries were deeply disturbed by World War II, Sweden had stayed outside the war, - and 
JOHN AAgE GJESTRUM

204 in fact during these years realised a big museum programme introduced by the National Antiquary Sigurd Curman (in position 1923-1946).

Sweden was in several contexts presented in Museum as the most advanced museum country in Europe. In 1960 Sweden was also the first Nordic country to host the ICOM General Conference.

Hence it is not surprising that almost half the number of articles from the Nordic countries are written by Swedes. The exact figures for the period 19481994 are:

Denmark 26 articles

Finland 10 articles

Iceland 1 article

Norway 20 articles

Sweden 43 articles

Some other observations are also possible. The difference between Sweden and the other Nordic countries is not only quantitative; more or less half of the articles from Denmark, Finland and Norway are monographs of the author's museum. However, less than $20 \%$ of the articles written by the Swedish authors are this kind of monographs. They are more engaged in different general museum subjects.

One of these subjects is the environmental issues. The important United Nations Conference on the Human Environment took place in Stockholm in 1972. Museum published a double-issue (1973/ 1-2) on Museums and Environment. The Swede Kjell Engström, at that time President of the International Union for the Conservation of Nature and Natural Resources, wrote the editorial. Here we can find one famous article of Georges Henri Rivière, introducing the ecomuseum, Bengt
Hubendick writes on Natural history museums and Bent Jørgensen on The new Zoological Museum, Copenhagen. Jørgensen's article can also be seen as an introduction to the ICOM General Conference in Copenhagen 1974.

Another observation is on how the articles are spread over the years. The Nordic articles as a whole are distributed like this:
1948-1959: 15
1960-1969: 10
1970-1979: 23
1980-1989: 35
1990-1994: 17

Until 1986 the Swedes dominate the representation from the Nordic countries. From then on the picture changes, and there are more Danish and Norwegian articles published than Swedish. The reason for this is probably that the Danish art historian Lise Skjoth entered the editorial board during 1985 .

A very direct result from the energy Lise Skjøth put into the journal was the issue Nordic museums today, published in 1988 (1988/4). In her editorial introduction she gives the following reason:

The five Nordic countries - Denmark, Finland, Iceland, Norway and Sweden - possess common roots. Our way of thinking is 'Nordic' and, with the exception of Finnish, our languages are so closely related that we manage to understand one another with a minimum of effort. Of course, there are significant differences between our countries, for example in term of defence or economic policy; but it is not entirely incorrect to view us as constituting a sort of European province (Museum 1988/4: 168).

The issue contains 16 articles covering many important aspects of the Nordic 
museum reality, and should be considered an important source to anybody looking for information on Nordic museums. Thor Magnussen, director of the National Museum of Iceland, writes the only article from Iceland published in Museum; from the other four countries there are 4-5 articles from each one. What is typical Nordic and not presented in this issue, however, is the Sami museums. The Sami people living across the boarders between Norway, Sweden, Finland and Russia in the north have in the 1970s and 80 s established their own museum system. Some of the Sami topics are covered in the article by Raili Huopainen (Finland) on the Provincial Museum of Lapland, - in the issue Museums of the Far North (Museum 1994/2), following the United Nations International Year of Indigenous Peoples 1993.

Lise Skjøth also has succeeded in realising another of her ideas in the editorial board: an issue has been dedicated to Focus on Women (Museum 1991/3). This issue was produced in a way never tried before: all the authors (seventeen women and one man!) were invited to a workshop in Copenhagen in June 1990, after a year and a half of preparations. The workshop concluded in a strategy of action to strengthen equality and how to improve the status of women in museums (1991/3: 125). A major question discussed was also: What about specical women's museums? One of the answers given to this question in the issue is by Jette Sandahl, curator of the Women's Museum of Denmark.

The bibliography of the Nordic articles in Museum that follows below counts 100 articles and should be almost a complete one. I suppose the total number of articles published in Museum during almost 50 years should be between 2.500 and 3.000 . The Nordic contribution in this perspective is less than $5 \%$. However, as the reading of Museum shows, at certain moments and in connection with specific topics, the Nordic influences have been significant. Not least in bringing new issues on the agenda which are no doubt also linked to subjects the Nordic countries on the highest level of UNESCO and United Nations want to promote.

\section{BIBLIOGRAPHY}

\section{DENMARK}

Berglund, Joel. «Recovering the past: the Greenland National Museum and Archives.) Museum 1994/2: 26-29.

Birkebaek, Frank. «What future for Danish museums?» Museum 1988/4: 183-185.

Crumlin-Pedersen, Ole. "The Viking Ship Museum of Roskilde: the saga of a new Danish museum.» Museum 1975/1: 17-21.

Damm, Annette. "Reinterpreting the Stone Age at Moesgård.» Museum 1987/2: 107-112.

Elgaard, Berit. «Museum librarian: everyone's partner.» Museum 1993/4: 48-51.

Gundestrup, Bente. «The Royal Danish Kunstkammer." Museum 1988/4: 186-189.

Haase, Peter N. «Educational activities in the framework of the Zoological Museum in Copenhagen (Denmark).» Museum 1979/3: 197-199.

Hansen, Hans Ole. "The historical workshop, Denmark: the Lejre Centre.» Museum 1975/1: 22-28.

Hansen, Tag Høyer. «The museum as educator.» Museum 1984/4: 176-183.

Jensen, Jørgen and Elise Thorvildsen. «Danish 
206 National Museum, Copenhagen.» Museum 1977/2-3: 131-134.

Jørgensen, Bent. «The new Zoological Museum, Copenhagen.» Museum 1973/1-2: 63-68.

Jørgensen, Bent. «From Pole to Pole. New exhibition hall at the Copenhagen Zoological Museum.» Museum 1975/3: 128-133.

Larsen, Svend. «Local museums of cultural history in Denmark.» Museum 1960/2: 76-78.

Larsen, Carsten U. "Collection management: the Danish case.» Museum 1988/4: 197-199.

Ludvigsen, Peter. «Peasants paintings from Nicaragua travel to Denmark.» Museum 1992/1: 20-23.

Paulsen, Jørgen. «Temporary Exhibitions in an Armoury Museum.» Museum 1951/1: 59-60.

Paulsen, Jørgen. «The Royal Armoury Museum, Copenhagen.» Museum 1961/2: 82-85.

Rasmussen, Holger. "City of Odense Museums." Museum 1960/2: 81-84.

Sandahl, Jette. "Voicing the unspoken in Denmark.» Museum 1991/3: 172-175.

Schultz-Lorentzen, Helge. «Return of cultural property by Denmark to Greenland: from dream to reality.» Museum 1988/4: 200-205.

Seeberg, Peter. «The Viborg Stiftsmuseum: a small museum with a message.» Museum 1976/4: 237244.

Skjøth, Lise. «Guest editorial: Nordic museums - a glance in the rear-view mirror.» Museum 1988/4: 168-169.

Skjøth, Lise. «Denmark's Louisiana Museum - age: Thirty; status: work-in-progress (interview with Knud W. Jensen.» Museum 1989/3: 160-164.

Skjøth, Lise. "This is a first (introduction of the issue: Focus on women).» Museum 1991/3: 124125.

Uldall, Kai. «Open Air Museums.» Museum 1957/1: 68-83.

Volsøe, H. «The new Zoological Museum in Copenhagen.» Museum 1964/1: 33-35(38).

\section{FINLAND}

Heinonen, Riitta. «Regional and local museums of the history of the finnish culture.) Museum 1959/1: 40-59.

Honkanen, Pekka. «The Sports Museum of Finland.» Museum 1988/4: 222-223.

Huopainen, Raili. «Managing change: the Provincial Museum of Lapland.» Museum 1994/2: 30-32.

Kehusmaa, Aimo. «Museums across frontiers - the Nordkalottmuseet.» Museum 1988/4: 210-212.

Peisa, Outi and Marketta Tamminen. «Finland: Why does every village want its own museum?» Museum 1988/4: 180-182.

Peltonen, Jarno Juhani. «The Helsinki City Museum, Finland.» Museum 1980/1-2: 51-55.

Peltonen, Jarno Juhani. «The role of applied arts museums today.» Museum 1988/1: 18-21.

Perkko, Mariliina. "Costumes as indicators of community." Museum 1993/3: 25-27.

Valanto, Sirkka. «The Museum of Finnish Architecture.) Museum 1990/3: 168-171.

Ålander, Kyösti Kalervo. «The Museum of Finnish Architecture, Helsinki.» Museum 1964/1: 10-14.

\section{ICELAND}

Magnusson, Thor. «Museums in Iceland.» Museum 1988/4: 177-179.

\section{NORWAY}

Andersen, Christian. «Natural history museums: let's get moving!» Museum 1988/4: 217-221. Blindheim, Martin. "Open Air Museum Norsk Folkemuseum, Oslo." Museum 1952/1: 68-69. Frøiland, Øystein. «Maritime Bergen, ahoy!» Museum 1990/2: 76-78.

Hagevik, Ellen Marie. «Svalbard Museum: the world's northernmost museum.» Museum 1994/2: 37-40. 
Haverkamp, Frode Ernst. «Founding an art museum in northern Norway.» Museum 1988/4: 224-226.

Heintz, Natascha. «The Norwegian National Council of Museums - what use?» Museum 1988/4: 174-176.

Herteig, Asbjørn E. «Bryggens Museum, Bergen.» Museum 1978/1: 46-51.

Ingvaldsen, Arne H. "Museum for a heath culture, Norway: a proposal.» Museum 1978/2: 94-102.

Kavli, Guthorm. "The modernization of the Kunst industrimuseum, Oslo." Museum 1952/1: 65-66.

Kolltveit, Bård. «From harbour to seaport - a challenge to maritime museums.» Museum 1990/2: 113-114.

Langaard, Johan H. "The Munch Museum, Oslo." Museum 1964/1: 2-5(9).

Liberg, Astrid. "Museum Co-operation with Schools.» Museum 1955/4: 251-254.

Molaug, Svein. «The Norwegian Maritime Museum organizes underwater archaeology." Museum 1983/1: 57-61.

Mørkved, Brynhild and Rob Barret. "Tromsø Museum: a showcase for nature." Museum 1994/2: 33-36.

Noss, Aagot. «Bringing costumes to life: an exercise in media documentation." Museum 1993/3: 2324.

Opstad, Jan-Lauritz. «A Van de Velde room at 64 degrees north.» Museum 1990/3: 157-159.

Sivesind, Johannes. «Sheltered employment to help shoulder responsibilities." Museum 1981/3: 146150.

Soleim, Peder A. «Museum of Fishery, Bergen.» Museum 1952/4: 225-234.

Svendsen, Sverre J. «Mellemværftet: a shipyard museum in Kristiansund.» Museum 1988/3: 123132.

"The Sonja Henie and Niels Onstad foundations.» Museum 1970/71/3: 222-223.

\section{SWEDEN}

Althin, Torsten. "The Atomarium of the Tekniska Museet.» Museum 1954/3: 167-170.

Andrén, Ann. "A Swedish paradox.» Museum 1985/2: 112-114.

Baehrendtz, Nils Erik, Arne Biörnstad, Ingmar Liman, and Per Olof Palm. «Skansen - a stocktaking at ninety." Museum 1982/3: 173-178.

Bergengren, Göran. "Automatic data processing in the registration of museum collections in Sweden.» Museum 1970/1: 53-56.

Bergengren, Göran. "Towards a total information system.» Museum 1978/3-4: 213-217.

Bergman, Helge. «Educational programmes of natural history museums in Europe.) Museum 1952/2: 73-79.

Biörnstad, Margareta. «Swedish museums: a brief history.» Museum 1988/4: 190-193.

Biørnstad, Arne. "Provincial Museums in Sweden.» Museum 1957/3: 208-227.

Engström, Kjell. «Museums and environment. Editorial.» Museum 1973/1-2: 2.

Engström, Kjell. «Temporary and travelling exhibitions: a means of providing information on nature conservation.» Museum 1973/1-2: 89-92.

Engström, Kjell. «The ecomuseum concept is taking root in Sweden.» Museum 1985/4: 206210.

Gejvall, Nils-Gustaf. «Prehistoric environmental destruction, Lerna (Greece).» Museum 1973/1-2: 94-96.

Grate, Pontus. "«Christina, Queen of Sweden", an exhibition in the National Museum, Stockholm.» Museum 1967/2: 141-146.

Hedvall, Johan Arvid. «Objects of cultural value and knowledge of materials.» Museum 1952/1: 39-45.

Hubendick, Bengt. "Natural history museums, tropical diseases and taxonomy.» Museum 1973/1-2 97-100.

Johansson, Hans and Bo Nilsson. «Museums infor- 
208 mation and communication technologies: the Swedish approach.» Museum 1988/4: 194-196.

Johnels, Alf G. «Role of natural history museums.» Museum 1973/1-2: 54-58.

Kaelas, Lili. "Cypros - Island of Conflict.

Exhibition of the Göteborg Archaeological

Museum." Museum 1976/2: 107-120.

Källström, Olle. «Use of plastic mounts for the specimens of goldsmith's art.» Museum 1952/2: 108109.

Kåks, Per. «Introduction. Programming for museums.n Museum 1979/2: 73.

Kvarning, Lars-Åke. "The Wasa: museum and museums exhibit." Museum 1984/2: 75-80.

Lindblom, Andreas. «Publicity and public relations." Museum 1951/4: 269-270.

Lundborg, Gun. «Reservoirs of technical variability: collect before erosion sets in.» Museum 1984/3: 126-129.

Lundström, Agneta. «Balancing the books at Svenska Museer.» Museum 1990/4: 219-220.

Madrid, Alfonso. "Work in historical osteology at the National Museums of Antiquities in Sweden.» Museum 1986/3: 155-157.

Nilsson, Bo and Bengt Rosén. "Cultural history museums and human ecology - a challenge to integration.» Museum 1988/4: 213-216.

Olofsson, Ulla Keding. «Beautiful Moments: an art exhibition with a shock effect." Museum 1970/1: 80-82.

Olofsson, Ulla Keding. "The role of museum in a decentralized cultural policy. Meeting of the International Committee of ICOM for Education and Cultural Action, Umeå, 1976.» Museum 1977/1: 52-55.

Olofsson, Ulla Keding. «Riksutställningar: from travelling exhibitions to an information centre." Museum 1986/4: 205-206.

Olofsson, Elisabet. «A professional exchange programme: Sweden-Africa.» Museum 1988/4: 206209.

Rydbeck, Monica. "A note on history museums."
Museum 1961/4: 198-201.

Selling, Gösta. «Educational Work in Swedish Museums.» Museum 1948/3-4: 130-133, 210 -.

Setterwall, Ake. "The Treassure Vault, Royal Palace, Stockholm.» Museum 1972/4: 244-248.

Stenklo, Ainar. «The Stora Kopparbergwerks Museum, Falun (Sweden).» Museum 1967/3: 218-219.

Strandh, Sigvard. «The Museum of Science and Technology, Stockholm.» Museum 1967/3: 188189.

Thordeman, Bengt. "Swedish Museums.» Museum 1949/1: 7-28(64).

Vahlquist, Gudrun. "Developing museums - part of Sweden's cultural policy.» Museum 1988/4: 171173.

Westerlund, Stella and Thomas Knuthammar. «Handicaps prohibited - travelling exhibitions in Sweden.» Museum 1981/3: 176-179.

Westerlund, Stella. "Twenty years of travelling exhibitions." Museum 1986/4: 206-212.

Wexell, Astrid. "Tactile pictures in Stockholm.» Museum 1981/3: 180-183.

Zachrisson, Sune. «Agricultural museums - the story and propagation of an idea.» Museum 1984/3: 121-124.

Agren, Per-Uno. «On the preparation of a new exhibit in the regional museum of Västerbotten (Sweden).» Museum 1976/3: 171-175.

"June 1990: a new museum for Sweden's famed Vasa warship.» Museum 1990/2: 87 (1 s.). 